\title{
Occurrence of Meloidogyne enterolobii in common bean in southern Goiás State, Brazil
}

\author{
Rodrigo Vieira da Silva ${ }^{* *}$ (D) José Orlando de Oliveira ${ }^{1}$ (D) José Humberto de Ávila Júnior ${ }^{1}$ (iD \\ Brenda Ventura de Lima $^{1}$ (iD) Nádia Fernandes Moreira ${ }^{1}$ iD
}

${ }^{1}$ Programa de Pós-graduação em Olericultura, Departamento de Nematologia, Instituto Federal Goiano, 75650-000, Morrinhos, GO, Brasil. E-mail: rodrigo.silva@ifgoiano.edu.br. "Corresponding author.

\begin{abstract}
Meloidogyne enterolobii is known as the most aggressive root-knot nematode (RKN) in Brazil. Common bean (Phaseolus vulgaris) cultivated in the experimental field in Morrinhos, Southern Goiás State, exhibited symptoms typical to those caused by RKN. In order to clarify the etiology of the disease, root systems were analyzed. Typical galls of varying thickness were observed, with thickening larger than $3 \mathrm{~cm}$ in diameter containing RKN females inside roots and egg masses on the root surface. The identification of the nematode species was confirmed by isoenzyme electrophoresis (esterase and malate dehydrogenase phenotypes). This is the first report of M. enterolobii in Goiás and in Brazil parasitizing common bean under field conditions. This result is an alert to producers and to the State phytosanitary defense authorities, in order to prevent the further dissemination of this pest, especially in fields of common bean and industrial tomato in the State.
\end{abstract} Key words: dissemination, esterase phenotype, Phaseolus vulgaris, root-knot nematodes.

Ocorrência de Meloidogyne enterolobii em feijoeiro no Sul Goiano

RESUMO: Meloidogyne enterolobii é considerada uma das espécies de nematoide de galhas mais agressivas presentes no Brasil. Feijoeiro (Phaseolus vulgaris) cultivado em um campo experimental em Morrinhos, na região sul do estado de Goiás, apresentou sintomas característicos de nematoide de galhas radiculares. Para esclarecer a etiologia da doença, os sistemas radiculares foram analisados. Foram observadas galhas típicas da infecção por Meloidogyne spp., com espessuras maiores que $3 \mathrm{~cm}$ de diâmetro, contendo em seu interior fêmeas e massas de ovos na superficie radicular. A identificação foi realizada por meio da eletroforese de isoenzimas (fenótipos esterase e malato desidrogenase). Este é o primeiro relato da diagnose em condições natural de campo de M. enterolobii em Goiás e no Brasil parasitando feijoeiro. Esta ocorrência deve servir de alerta aos produtores e às autoridades de defesa fitossanitária do Estado, a fim de impedir a disseminação desse patógeno, principalmente nos campos da produção de feijoeiro e tomate industrial em Goiás.

Palavras-chave: disseminação, fenótipo de esterase, nematoide de galhas, Phaseolus vulgaris.

The species Meloidogyne enterolobii Yang and Eisenback (1983) syn. M. mayaguensis Rammah and Hirschmann (1988) was described from roots of Enterolobium contortisiliquum (Vell.) in China. This is considered the most aggressive of the rootknot nematode (RKN) species. This fact is due to its high reproduction rate, substantial damage to plant, with the induction of large galls, wide host range and worldwide distribution, as well as its ability to overcome plant resistance, e.g., tomato, soybean and potato (CARNEIRO et al., 2001), beside peppers (CARNEIRO et al., 2006).

In Brazil, M. enterolobii causes great damages and economic losses to vegetables, guava and tropical fruit trees. Therefore, knowing its possible hosts is of great importance for the adoption of adequate preventive and control measures. Little is known about these hosts, except for some such as guava, corn, cucumber, tomato, and pumpkin. In addition, it's important to report that in a recent study carried out in Brazil, with ten banana cultivars, six Barbados cherries, one fig, two grape rootstocks and six melons were good hosts allowing high reproduction of $M$. enterolobii (FREITAS et al., 2017).

In March 2017, in Morrinhos, Southern Goiás State, Brazil, common bean plants (Phaseolus vulgaris) were reported to be severely infected by $\mathrm{RKN}$ in an experimental field cultivated with snap bean cultivars. All cultivars analyzed: Bush Sword, Commodore Improved, Contender, Delinel, 
Festina, Hab 1º Hab 39, Hab 46, Improved Golden Wash, Japanese Bank, Japanese Yellow, Maxibel, Napoli, Provaider, Slenderwarx, Stringless Green, Strike Tendergreen Improved, Tenderette and Tourmaline were infected by the nematode. The plants showed thickening in the roots, symptoms of dwarfism, generalized yellowing, drastic reduction in productivity and even death of several plants.

In order to clarify the etiology of the disease, samples of infected roots were collected and analyzed in the Laboratory of Agricultural Nematology. The roots with galls were dissected and females were extracted from the galls and transferred to $0.5 \mathrm{~mL}$ eppendorf tubes. To verify the species, a preliminary analysis was performed by the perineal pattern study (TAYLOR \& NETSCHER, 1974).

For the biochemical identification of the species, females were removed from galls in bean roots and placed in eppendorf tubes containing $10 \mu \mathrm{l}$ of protein-extracting solution. The obtained protein extracts were applied in polyacrylamide gel following the vertical electrophoresis technique in a discontinuous of the esterase (EST) and malate dehydrogenase (MDH) enzymes, according to the methodology described in FREITAS et al. (2016).
The bean roots were presented with many protruding, coalescing root galls with several females in their interior. These symptoms and signs are typical of RKN, however, unlike the symptoms observed by the infection of $M$. incognita and $M$. javanica in beans, the galls were quite large, reaching more than $3 \mathrm{~cm}$ in diameter (Figure 1). Moreover, the attack was so intense that the plants did not produce, making the experiment unfeasible.

The analysis of the perineal configurations was not conclusive, because the perineal patterns of some females had a high trapezoidal dorsal arch similar to that of $M$. incognita, furthermore most of them exhibited great variability. This variability on perineal patterns and the similarity with $M$. incognita are the reasons which this taxonomic feature can not be exclusively used for the identification of $M$. enterolobii (ESBENSHADE \& TRIANTAPHYLLOU, 1990).

In the biochemical analysis, esterase (Est $=\mathrm{M} 2, \mathrm{Rm}: 0.7$ and 0.95) and malate dehydrogenase $(\mathrm{MDH}=\mathrm{N} 1 \mathrm{a}, \mathrm{Rm}: 1.4)$ phenotypes presented characteristic patterns of $M$. enterolobii species (Figure 2). However, for a better characterization of this nematode population, more refined phylogenetic studies and complete diagnosis

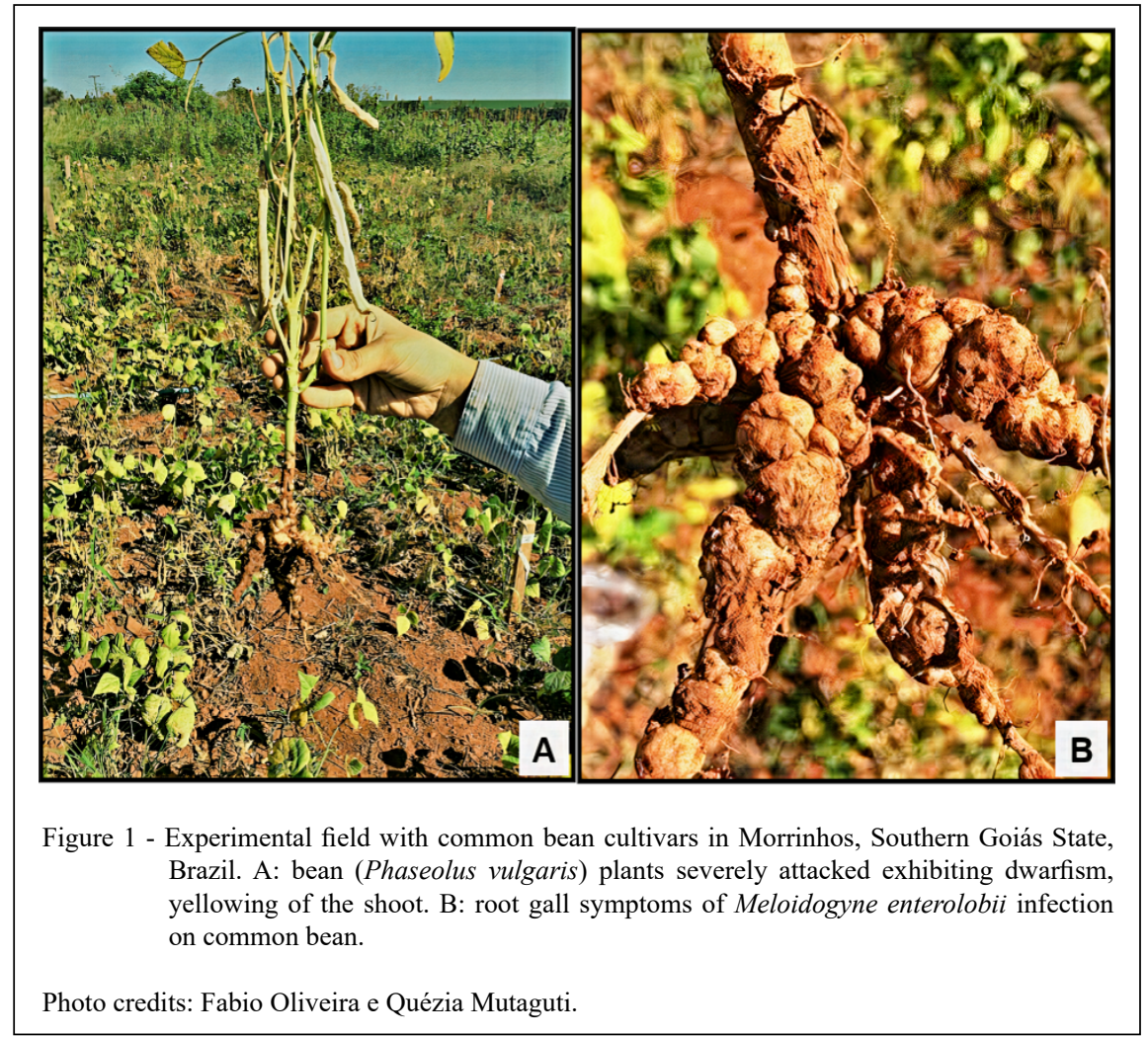

Ciência Rural, v.51, n.10, 2021. 


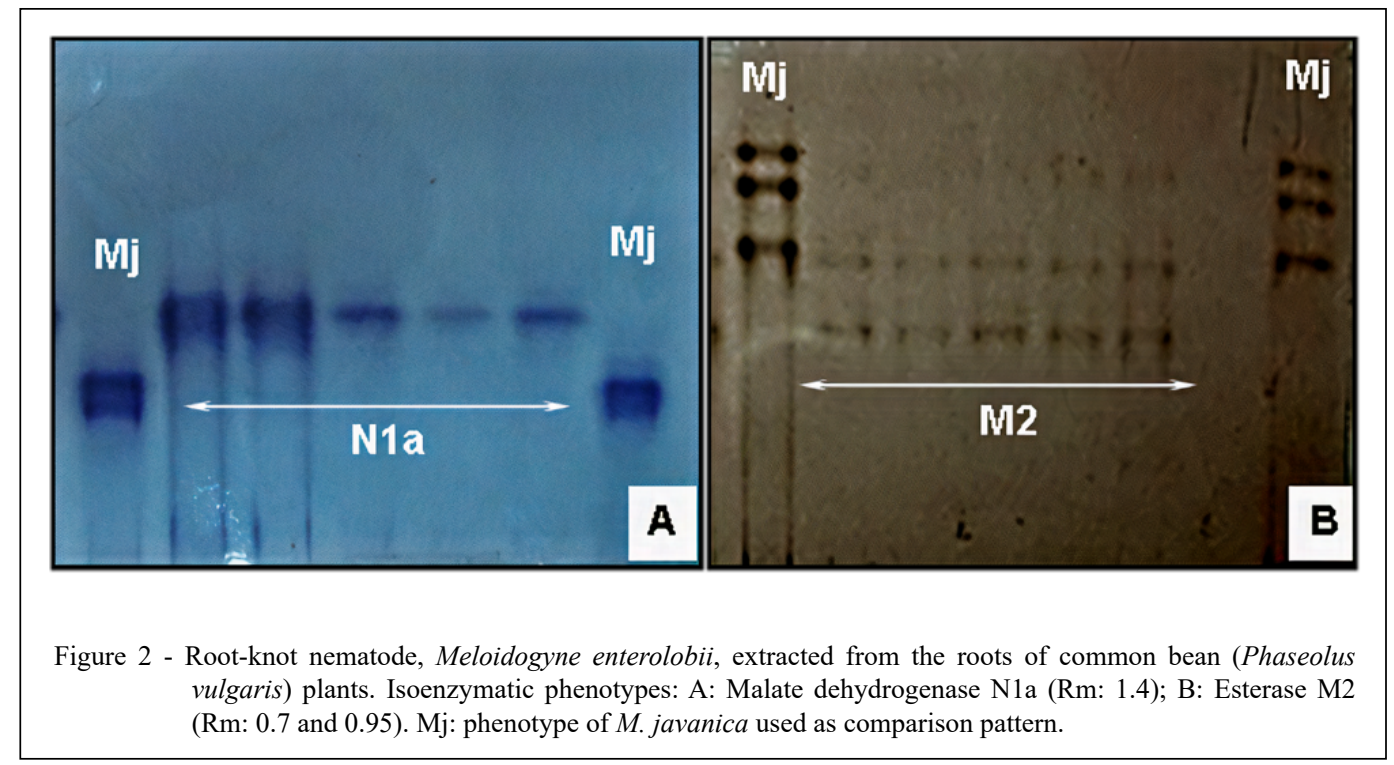

using molecular techniques is also recommended (CUNHA, et al., 2018).

To prove the pathogenicity of this population of M. enterolobii, it was inoculated in six bean plants of the Pérola cultivar, one of the most cultivated in the region. It was verified an average reproduction factor $(\mathrm{RF}=$ final nematode population/ initial nematode population, OOSTENBRINK (1966) of 16.6 after 60 days of multiplication.

The same M. enterolobii population was also able to infect and reproduce in tomato (Solanum lycopersicum) cv. Santa Cruz kada $(\mathrm{RF}=10.8)$ and Giboma (solanum macrocarpum) $(\mathrm{RF}=12.4)$.

This nematode species was probably already present in soils in the Cerrado region, but poorly identified, since its morphological characteristics are very similar to $M$. incognita, which is the most widespread RKN in the region, especially in soybean and vegetables. With the improvement of the electrophoresis technique for nematode analysis, it was possible to characterize biochemically described RKN species, in addition to elucidating atypical phenotypes, and detecting mixed populations in the same cultivation field (CARNEIRO et al., 2001). This technique also allowed to conclude that many populations identified as $M$. incognita, were actually, $M$. enterolobii (CARNEIRO et al., 2001). The dissemination of $M$. enterolobii in Brazil has been increasing in recent years. The presence of $M$. enterolobii was reported in producing regions in the state of Ceará, standing out as one of the species with the highest number of hosts, among fruit trees, vegetables and weeds (SILVA et al., 2016). The newest report of this species in Brazil on a new host occurred in banana cultivation in 2018 (LUQUINE et al., 2019).

In the state of Goiás, the most common RKN species in agricultural crops are M. incognita and $M$. javanica. In the case of $M$. enterolobii, there were only reports in Goiás State, in two cultivation fields, in the cities of Formosa and Luziânia, infecting guava, Psidium guajava cv. Paluma, and papaya, Carica papaya cv. Formosa (SIQUEIRA, et al., 2009).

The official registration of $M$. enterolobii (syn.: M. mayaguensis) in the Brazilian territory occurred in 2001 (CARNEIRO et al., 2001). However, due to the great potential to cause high damage to national agriculture, several studies regarding its management in infested areas are being carried out in order to avoid further impact by the attack of this pathogen. Until now, there was no report of the occurrence of M. enterolobii in beans in field conditions, only studies with artificial inoculation in greenhouse conditions, where in one of the studies, all genotypes were susceptible, except for the cultivar Aporé, classified by the authors as resistant, despite presenting RF $>1$ (MELO et al., 2011). In another study, both Phaseolus vulgaris cv. IPA-9 and Vigna unguiculata $\mathrm{cv}$. IPA-206 were highly susceptible to $M$. enterolobii with a RF of 48.97 and 38.92, respectively (GUIMARÃES, et al., 2003). This demonstrated the great potential of this nematode species to cause damage to beans.

Ciência Rural, v.51, n.10, 2021. 
The use of resistant cultivars is a recommended measure to control plant nematodes. In the case of RKN, one of the most efficient and studied genes is the $M i$ gene that confers resistance to the main species, namely $M$. incognita, $M$. javanica and $M$. arenaria. However, it does not provide resistance to M. enterolobii (CARNEIRO et al., 2006). The southern region of Goiás is the main industrial tomato producing region in the country with 1.3 million tons, corresponding to about $80 \%$ of the national production (IBGE, 2019). A danger would be the spread of this nematode to this crop, which is practically $100 \%$ irrigated, condition that favors the multiplication and spread of these nematodes.

This study constituted the first report of the diagnosis of $M$. enterolobii, parasitizing common bean in natural field conditions in Brazil. This population of $M$. enterolobii is capable of infecting beans with a high reproductive rate and making production unfeasible. This fact should serve as an alert to producers and the State's phytosanitary protection, in order to prevent dissemination, especially, in areas of irrigated common bean and tomato.

\section{ACKNOWLEDGMENTS}

To Conselho Nacional de Desenvolvimento Científico e Tecnológico (CNPq) and Fundação de Amparo à Pesquisa do Estado de Goiás (FAPEG) for granting scholarship and to Instituto Federal Goiano for the funding resources to carry out this work. And was also financed in part by the Coordenação de Aperfeiçoamento de Pessoal de Nível Superior (CAPES), Brasil - Finance code 001.

\section{DECLARATION OF CONFLICT OF INTEREST}

The authors declare no conflict of interest. The Sponsors had no role for the design and writing of the manuscript, and in the decision to publish the results.

\section{AUTHORS' CONTRIBUTIONS}

All authors contributed equally for the conception and writing of the manuscript. All authors critically revised the manuscript and approved the final version.

\section{REFERENCES}

CARNEIRO, R. M. D. G. et al. First record of Meloidogyne mayaguensis in guava in Brazil. Nematologia Brasileira, v.25, p.223-228, 2001. Available from: <https://nematologia.com.br/ files/revnb/25_2.pdf>. Accessed: Apr. 13, 2019.

CARNEIRO, R. M. D. G. et al. First record of Meloidogyne mayaguensis parasitizing tomato and pepper plants resistant to myeloidoginosis in the State of São Paulo. Nematologia Brasileira, v.30, p. 81-86, 2006. Available from: <https://nematologia.com.br/ files/revnb/30_1.pdf>. Accessed: Mar. 12, 2019.
CUNHA, T. G. et al. Diagnostic methods for identification of root-knot nematodes species from Brazil. Ciência Rural, v.48, e20170449. 2018. Available from: <http://www.scielo.br/scielo.ph p?pid=S010384782018000200153\&script=sci_abstracttlng=en $>$. Accessed: Apr. 18, 2020. doi: 10.1590/0103-478cr20170449.

ESBENSHADE, P. R.; TRIANTAPHYLLOU, A. C. Isozyme phenotypes for the identification of Meloidogyne species. Journal of Nematology, v.22, p.10-15, 1990. Available from: <https://www.ncbi. nlm.nih.gov/pmc/articles/PMC2619005/>. Accessed: Apr. 10, 2020.

FREITAS, L. G. et al. Methods in Plant Nematology. In: ALFENAS, A.C.; MAFIA, R.G. Methods in Phytopathology. Viçosa: Universidade Federal de Viçosa, 2016. $2^{\circ}$ Ed. Cap.11, p.275-296.

FREITAS, V. M. et al. Host status of selected cultivated fruit crops to Meloidogyne enterolobii. European Journal of Plant Pathology, v.148, p. 307-319, 2017. Available from: $<$ https://ainfo. cnptia.embrapa.br/digital/bitstream/item/180660/1/Freitas2017Article-HostStatusOfSelectedCultivated.pdf $>$. doi: 10.1007/ s10658-016-1090-8. Accessed: Apr. 12, 2020.

GUIMARÃES, L. M. P. et al. Meloidogyne mayaguensis parasitism in different botanical species. Nematologia Brasileira, v.27, p.139-145, 2003. Available from: <https://nematologia.com. br/files/revnb/27_2.pdf>. Accessed: Mar. 18, 2020.

IBGE, Instituto Brasileiro de Geografia e Estatística, Systematic survey of agricultural production. 2019. Available from: $<$ https:// biblioteca.ibge.gov.br/visualizacao/periodicos/2415/epag_2019_ jan.pdf>. Accessed: Sept. 13, 2020.

LUQUINE, L. et al. First report of the root-knot nematode Meloidogyne enterolobii on bananas in Brazil. Plant Disease, v.103, p.377, 2019. < https://apsjournals.apsnet.org/doi/10.1094/ PDIS-04-18-0602-PDN> Accessed: Apr. 20, 2020. doi/10.1094/ PDIS-04-18-0602-PDN.

MELO, O. D. et al. Screening of vegetable genotypes for resistance to Meloidogyne enterolobii. Pesquisa Agropecuária Brasileira, v.46, p. 829-835, 2011. Available from: < https://seer.sct.embrapa.br/ index.php/pab/article/view/10405/6506>. Accessed: Apr. 15, 2020.

OOSTENBRINK, M. Major characteristics of the relation between nematodes and plants. Mededelingen der Landbouwhogeschool, v.66, p.3-46, 1966.

SILVA, M. C. L. et al. Meloidogyne species associated with vegetables in microregions of the state of Ceará. Revista Ciência Agronômica, v.47, p.710-719, 2016. Available from: $<\mathrm{http}: / / \mathrm{http}: / /$ www.scielo.br/pdf/rca/v47n4/1806-6690-rca-47-04-0710.pdf> Accessed: Apr. 14, 2020. doi: 10.5935/1806-6690.20160085.

SIQUEIRA, K. M. S. et al. Detection of Meloidogyne mayaguensis in guava and papaya in the state of Goiás, using molecular markers. Tropical Plant Pathology, v.34, p.256-260, 2009. Available from: <http://www. scielo.br/pdf/tpp/v34n4/v34n4a09.pdf>. Accessed: Mar. 18, 2020.

TAYLOR, A. L.; NETSCHER, C. An improved technique for preparing perineal patterns of Meloidogyne spp. Nematologica, v.20, p. $268-269,1974$.

YANG, B.; EISENBACK, J.D. Meloidogyne enterolobii sp. (Meloidogynidae) a root-knot nematode parasiting pacara earpod tree in China. Journal of Nematology, College Park, v.15, p.381391, 1983. 